\title{
14 After Language Standardization: Dialect Cosplay in Japan
}

\author{
Patrick Heinrich
}

\section{Introduction ${ }^{1}$}

The rise of industrial, modern societies led to the emergence of standard languages across the world. In line with modernist ideologies that accompanied the rise of modern societies, principles such as universality, homogeneity, monotony and clarity were embraced and promoted (Bauman, 1992). Language was also regulated along these lines of thought, or, seen the other way around, variability and plurality in language were perceived as a problem. Since the sociolinguistic situation in which language modernisation and standardisation took place differed between countries, and because these processes occurred in different sociocultural and political situations, the developments and outcomes of language modernisation and standardisation also differ. The case of Japan deserves particular attention, because Japanese was the first-ever non-Western language to be modernised and standardised (Coulmas, 1985: 248-257). Doing so proved wrong the dominant orientalist ideology of the 19th century that only Western languages could be carriers of modern ideas and expressions. Proving these orientalist views wrong required a particular fervour in language modernisation and standardisation on the part of Japanese language planners. Consequently, the linguistic situation in Japan became 'exceedingly modern', i.e. extremely homogenous, monotonous and clear (Heinrich, 2012).

The trend of language standardisation has now been reversed. In the past 30 years, language has been de-standardising in Japan. De-standardisation, in a broad sense, refers processes where new linguistic forms, often developed on the basis of local dialects, are integrated into the standard language system (Sanada, 2000: 127). De-standardisation involves a change of language awareness (Yamashita et al., 2011), a critical reflection on norms (Noro \& Yamashita, 2001), changes of language use (Machida, 2009) and a diversification and growing mobility of speakers 
of Japanese (Murata, 2015). It involves all levels of linguistic description, and it manifests across all social strata. Language de-standardisation has never been comprehensively addressed for the case of Japan, and this chapter is no exception. I focus here merely on one of the latest stages of language de-standardisation, namely on what is called 'dialect cosplay' (bōgen kosupure) in Japanese. This phenomenon is particularly prevalent among the young and middle-aged generation, and it is driven by speakers in urban areas (Heinrich, 2018a; Tanaka, 2011).

Japanese dialect cosplay involves linguistic transgression. Transgressions into languages and varieties not commonly associated with the identity of a speaker have been observed in a number of other countries, too. Linguistic transgressions have been studied, for example, as 'crossing' in the UK (Rampton, 2005), as 'Kiezdeutsch' in Germany (Wiese, 2012), as 'Verlan' in France (Nieser, 2007), as 'straattaal' in the Netherlands (Cornips, 2012) or as 'Chicano' (Eckert, 2008) in the United States. Compared to other cases of linguistic transgression, two phenomena are worthy of note for Japan. Firstly, contrary to all other cases, Japan has a small migrant population. Linguistic transgressions do therefore not draw on migrant languages but on regional dialects. Secondly, language standardisation in Japan is very advanced. Across large parts of Japan, young and middle-aged people claim not to speak or know local dialects (Aizawa, 2012; Tanaka et al., 2016), and many speak regionally unmarked language as their vernacular language (in the sense of Labov, 1992). Local dialects in Japan once carried a strong stigma (Sibata, 1958), but since many no longer speak traditional dialects, many are now free to use 'dialect tokens' that they pick up, frequently also from popular culture and media.

Central to our analysis of dialect cosplay here is the notion of 'enregisterment', defined by Asif Agha (2007: 81) as 'processes and practices whereby performable signs become recognized (and regrouped) as belonging to distinct, differentially valorized semiotic registers by a population'. In the following, I analyse dialect cosplay in Japan as a process whereby dialect tokens index specific roles ('costumes') though a process of enregisterment. Sociocultural values of 'warmness', 'cuteness', 'coolness', 'manliness', 'femaleness', etc. are thereby 'not a static property [...] but a precipitate of socioculturally locatable practices' (Agha, 2003: 232). Put more simply, engaging in dialect cosplay involves the appropriation of linguistic elements that are not associated with the speaker's habitus in order to evoke a 'figure', in the sense of Goffman (1979). That is to say, these figures are detached from the linguistic identity of the speaking subject.

In this chapter, I will first briefly summarise the language standardisation process in Japan, before turning to an outline of language de-standardisation. As part of the outlook on present-day language de-standardisation in Japan, I will conclude with some methodological 
considerations on the study of standard and dialect. The chapter largely presents research conducted by scholars in Japan. My contribution here is simply to put these different strands into perspective and discussing them with also regard to frameworks and concepts developed outside of Japan.

\section{Language Standardisation in Japan}

Language standardisation in Japan is often said to have started during the Tokugawa Shogunate (1603-1868), when local clan leaders and their families had to take alternate residence in Edo (renamed Tōkyō in 1868). The clan leaders' wives and children had to permanently stay in Edo, and the various dialects that these long-time visitors spoke resulted in what is called 'Edo common language' (Edo kyōtsūgo) in Japanese sociolinguistics (Mizuhara, 1994). The clans and their entourage settled west of the city centre (a part of Tōkyō called 'Yamanote'), and it is from there that Standard Japanese would emerge after the Meiji Restoration of 1868 (Nomura, 2013).

After the forced opening of Japan in the mid-19th century, an awareness grew that Japan was facing a language crisis. In line with the then dominant 'language-as-an-organism' theory promoted by German philologist August Schleicher, non-Western languages were then universally seen as being 'poor in grammar' in modern linguistics, and therefore forever unable to be the carriers of modern concepts and developments (Garvin, 1993). The combination of language problems and negative Western language ideology led to an obsession with what was called 'national language problem' (kokugo mondai) at the time. Discussions about the perceived 'national language problem' led in 1890 to the dispatching of a Japanese student to Germany to find ways of 'improving Japanese' and to 'solve the national language problem' (Katō, 1880: 150). This student was Ueda Kazutoshi (1867-1937), who would become the first linguistics professor of Japan and the most influential person with regard to language modernisation and standardisation in Japan (Coulmas, 2016: 169-179). Inspired by the German language standardisation that Ueda had witnessed during his stay in Germany (Shimizu, 1990), Ueda organised dialect surveys across Japan that led to the publication of various reports. One of these was a two-volume work, published in 1916 and 1917, on what was proclaimed to be a Grammar of Spoken Japanese (Kokugo Chōsa I'inkai, 2000). This grammar would serve as a basis to teach a unified and standardised Japanese across the Japanese education system.

Before efforts to standardise Japanese in the early 20th century, a unified spoken Japanese language did not exist, nor was there such a unified language in Tōkyō. During the period of language modernisation and standardisation, Tōkyō experienced great demographic changes. The samurai who had accounted for almost half of the population at the time of the Meiji Restoration largely left the city and returned to their home 
provinces. These former residents of Yamanote were replaced by a new class of bureaucrats, police officers, scholars and students. Tōkyō, just like any other large city, is made up of millions of rural migrants. These migrants kept adding linguistic diversity to Tōkyō, while the language was being modernised and standardised (Heinrich \& Yamashita, 2018). At the end of the 19th century, we can find three different types of speakers in Tōkyō. Firstly, there were speakers of Edo common language; secondly, migrant speakers adapting to this language and, thirdly, Japanese dialect speakers. Unsurprisingly, given the amount of migration to Tōkyō, the population grew from 1.3 million in 1889 to 7.5 million in 1945 - the linguistic integration of these migrants into an imagined and idealised homogenous standard-speaking community became the linguistic order of the day. Anything that was not 'standard language' was viewed with suspicion, became subject to suppression and was earmarked for extinction. This included also the dialect spoken in the eastern part of Tōkyō known as Shitamachi, and, as the city kept expanding westward from Yamanote onwards, also the adjunct Tama dialect (Sugimoto, 2014: 309).

Literature played a central role in the diffusion of a unified language among adults at the time. Modern literature about everyday modern life by authors such as Futabatei Shimei (1864-1909), Yamada Bimyō (18681910) or Natsume Sōseki (1867-1916) used a newly developed 'write as you speak style' (genbun itchi-tai), and this 'written style of spoken Japanese' played a major role in the diffusion of Standard Japanese until 1945 (Heinrich, 2005). Putting 'spoken language' through the medium of writing resulted in a 'polished' and 'cultivated' speech that was perceived to be 'middle-class Western Tōkyō language'. The educated class of bureaucrats, teachers and students who settled in Yamanote were voracious readers of these works of literature (Nomura, 2013). They used these works also a model for their own speech in their efforts to assimilate themselves linguistically. It was also the language of these novels that would be used in the Japanese education system (Osa, 1998) and in the newly emerging genre of 'public debate' (Nomura, 2011). The language of these novels, and the way of learning and imitating this speech in Yamanote by the new, educated residents of Yamanote, would become the basis of Standard Japanese (Inoue, 2006). Those who spoke the Shitamachi dialect of the eastern part of the city were strongly affected by this. Their language came to index 'working class' while that of the imagined speaker of Yamanote came to index 'middle class' (Tanaka, 1999: 94-96). In this way, the 'new town' of Meiji-period Yamanote came to dominate the old, downtown part of Shitamachi. The language spoken in Yamanote would spread across Japan as Standard Japanese while that of Shitamachi became to be seen as yet another Japanese dialect, and hence as undesirable and inadequate for modern life. All the while, Standard Japanese was seen then and continues to be so until today, as the language of educated speakers from Tōkyō. 
Japanese was not only modernised and standardised but also ideologically and morally loaded (Lee, 2010). Masiko (1997: 68-70) comments about this ideological loading that the 'educated speech' of Tōkyō came to be considered as 'good language' while all other local and social varieties became seen as deviations. The grammar of the standard variety was treated as an extension of the grammar of written Japanese, and it thus provided for a link of such language to the (written) past and to the canon of premodern literature. Standard Japanese was uncritically accepted as 'educated', 'refined' and 'correct'. Backed by the state-supported Grammar of Spoken Language (Kokugo Chōsa I'inkai, 2000), which was first published in 1916, Standard Japanese was spread with much fervour across Japan. While proficiency in Standard Japanese remained unevenly distributed before 1945, an awareness of correctness and the symbolic domination of standard speakers over dialect speakers spread everywhere, and it came to affect everyone (Heinrich, 2013; Okamoto \& Shibamoto-Smith, 2016: 28-49). As a rule of thumb, the further away from Tōkyō and the greater the linguistic difference and distance to Standard Japanese, the greater the disregard for the respective dialect, and the greater the pressure to adapt to Standard Japanese.

By defining the standard variety as the model for the written language, the sense of national unity through language was furthermore enhanced. The norm and prestige of the written language was instrumental in sustaining the superior position of the standard language over Japanese dialects. Sibata (1977) has famously noted that Japanese dialects attained their negative image exactly at the same time when Ueda and the National Language Research Council took up their work of establishing Standard Japanese. As an effect, Shibata (1979: 29) writes, dialects came to be perceived as 'wrong' (tadashikunai), 'bad' (warui) and 'old-fashioned' (furukusai), thus as the exact opposite of Standard Japanese, which was seen as 'good' (ii) and 'correct' (tadashii) language. This kind of awareness and the institutional support that Standard Japanese enjoyed had dramatic effects on language use across Japan. After all, speaking is not simply an activity of 'transmitting ideas' but also a means 'to do things' and 'to be someone', and the things that could be done in dialect and the person one could be as a dialect speaker had been crucially reduced (see Hiramoto, this volume for dialect use outside of Japan).

The diffusion of standard language across Japan initially differed to a great extent. Peripheral areas such as Tōhoku in the northeast and Kyūshū in the southwest initially lagged behind (Jugaku, 1978), and this led to notably higher levels of embarrassment about local dialect in these regions as well as the ever-increasing pressures to adopt Standard Japanese there (NHK, 1979). This situation gradually changed after 1950, because most Japanese then acquired standard language from an early age onwards, often already in the family. A long-time survey by the Japanese Institute of Japanese Language and Linguistics conducted in Tsuruoka City in the 
northeastern Tōhoku region showed that in 2011 everyone spoke Standard Japanese. What is more, the vast majority remembered only tokens of the local dialect that had once been spoken there (Kokuritsu Kokugo Kenkyūjo, 2013). In post-war Japan, it became commonplace to speak Standard Japanese. In particular, everybody born from the 1990s onwards has usually been socialised only in the standard language. It is exactly at this point in time that we find a reversal of trends. Ever since the 1990s, language is de-standardising in Japan (Inoue, 2011; Sanada, 2000).

\section{After Standardisation}

Due to the thorough spread of standard language in post-war Japan, language repertoires and language attitudes have fundamentally changed. The middle and young generations are no longer insecure about the boundaries of dialect, and standard language is now the language variety they use with the least effort (Sanada, 1996a), i.e. as their vernacular language. The ability to produce standard language without effort and linguistic self-monitoring has freed most Japanese from the linguistic insecurity that had once accompanied dialect speakers. Today, the majority of Japanese speakers are no longer engaged in 'passing' (Renfrow, 2004) as a standard language speaker. Passing refers here to a social agency of linguistic self-monitoring and self-censure and correction in order to produce standard language. ${ }^{2}$ With standard language being the basic strata of language repertoires, we find today a new appreciation of dialects in Japan (Tanaka et al., 2016). It is this positive attitude, together with token knowledge of various regional dialects in Japan, that results in new language uses. Note, however, that more has changed than just the use and the structure of standard and dialect since the 1990s. This is already obvious from the fact that dialect and standard can no longer be captured as two distinct systems used in separate domains or settings (Kobayashi, 2018; Satō \& Yoneda, 1999). As an effect of changing language attitudes and repertoires, differences have become fluid, and domains where what kind of language is used have become hard to predict (Okamoto \& Shibamoto-Smith, 2016: 74-122; see Zhao, this volume for a similar development in the People's Republic of China).

\section{Language de-standardisation}

It has often been observed that language de-standardisation has become a notable and persistent trend in Japan from the 1990s onwards (e.g. Inoue, 2011). This notwithstanding, Standard Japanese is of course still around and so are the language ideologies that accompanied its creation and spread. We can still find domains where Standard Japanese is used without fail, for example in TV broadcasts of Japan's national public 
broadcasting organisation NHK. Standard Japanese is used there because viewers expect public broadcasting to set an example of 'good' and 'correct' speech (Shioda, 2011). However, with a shift from dialect to standard language in private domains and, therefore, with processes of dialect levelling and loss, we can also find 'mixed' language uses, or 'relaxed' uses of (Standard) Japanese in an ever-growing number of settings today. Sanada (1996b) discusses these as new Japanese varieties, distinguishing between what he calls 'neo-dialects' and 'quasi-standard language'. 'Neodialects' refers to a use of language that is neither dialect not standard, but somewhat between the two, while quasi-standard is standard language with purposeful interferences from dialect, for example with regard to accent. Linguistically, the boundary between neo-dialect and quasi-standard is fluid, but there is a clear division between the two in the minds of the speakers.

Language is always fluctuating and always shows variability, but there is a tipping point when users start noticing that two variants are used at the same time across a speech community. In Japanese sociolinguistics, this tipping point is referred to as kotoba no yure, literally, 'swaying of language'. When a new variant or linguistic innovation is used by about three quarters of the speech community, it becomes accepted as common use (Inoue, 2011). Several researchers in Japan have observed that new attitudes towards and new uses of language have spread to such an extent from the 1990s onwards that they declare this period to mark the end of the standardisation process (Sanada, 2000). Japanese sociolinguists such as Tanaka (2007) state that underlying these new uses of language are attitudes such as 'amusement' (goraku), which renders dialects a 'toy to play' around with (omocha-ka), or an 'accessory' to beautify language (akusesōri-ka). To this end, features from all kinds of social and regional varieties are incorporated into Tōkyō colloquial speech, which is then spreading through popular media across Japan (Inoue, 2011: 122). ${ }^{3}$

The study of Japanese that is neither standard nor dialect was once seen as studying the emergence of new linguistic systems, and linguists sought to capture it as such (e.g. Inoue \& Yarimizu, 2002). This perception is changing now. Language de-standardisation is no longer seen as resulting in a new system, but as resulting in constant and often spontaneous innovation within an existing system. Change is the effect of creatively 'crossing' into new repertoires and identities (see Abe, this volume). Underlying these transgressions is more than simply 'fun' or 'decoration' (see above), as such linguistic behaviours reflect changing language attitudes. Today, de-standardisation involves cool, spontaneous and innovative stylisation of speech (Maher, 2005), where 'cool' has taken the place of 'correct', in particular among all those born from the 1990s onwards (Heinrich, 2018b; Heinrich \& Galan, 2018). 


\section{Dialect cosplay}

Cool language use is very much the opposite of 'speaking correctly' or 'speaking with authority', because coolness is in principle 'a rebellious attitude, an expression of a belief that the mainstream mores of your society have no legitimacy and do not apply to you' (Pountain \& Robins, 2000: 23-24). Such language use requires a distancing from sources of authority and notions of correctness. This kind of distancing is not achieved by confrontation (which is totally uncool) but through flouting the system and the practices on which authority, correctness and legitimacy are based. Simply put, one stops playing by the conventional rules that underlie authority, correctness and legitimacy. As a result, all language variation that was once suppressed during the language standardisation process now serves as a potent means for cool language stylisation. This manifests in attitudes towards standard language and local dialects in contemporary Japan. Consider some recent data on the perception of standard language and local dialect in Japan (Figure 14.1). The regions are listed geographically from north to south, starting in the northeast in Tōhoku and ending in the south in Kyūshū.

Figure 14.1 shows that, aside from Greater Tōkyō and to some extent the adjacent North-Kantō region, local dialects are more appreciated than standard language in contemporary Japan. What is more, in regions where local varieties were most fervently suppressed during the spread of standard language (e.g. Kyūshū), appreciation runs highest. Note in passing that Hokkaidō and Okinawa are omitted from our discussion here. The former is a settlement colony where we find a koine rather than a dialect. Okinawa, on the other hand, is home to the Ryukyuan languages,

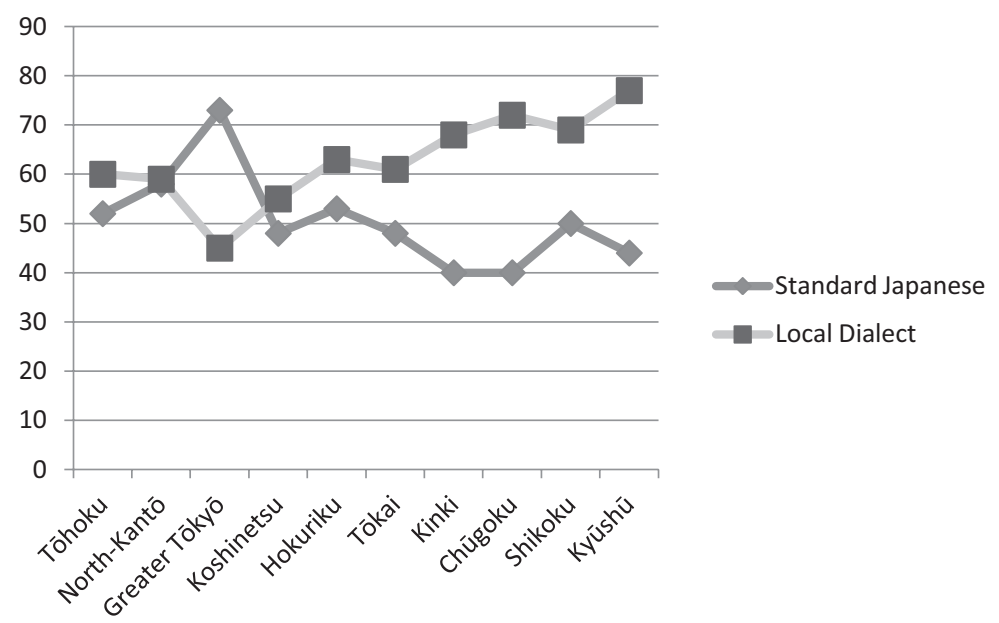

Figure 14.1 How much do you appreciate your dialect and the standard language? Source: Adapted from Aizawa (2012: 30) 
making the sociolinguistic situation there more complex than in other parts of Japan (Heinrich et al., 2015). We thus arrive at a situation in which standard language is appreciated more highly than dialects only in Tōkyō and in its immediate geographic periphery. This has also to do with the fact that standard language is largely based on Tōkyō language and innovations and that other dialects in and around Tōkyō were replaced by standard language faster than anywhere else in Japan. As a matter of fact, in these areas, we find little knowledge about the dialects that were once spoken there. In a survey conducted in 2015, a whopping $90 \%$ of the informants from Tōkyō replied to the question about whether a Tōkyō dialect existed with either 'no' or 'I don't know' (Tanaka et al., 2016).

Two things are important to understand present-day language destandardisation in Japan. In addition to a newfound appreciation of local dialects in Japan, the majority of young and middle-aged Japanese have been socialised as standard language speakers. This implies that they no longer speak local dialects in everyday life, even if they come from peripheral parts of Japan where standard language had spread later and more slowly. Most Japanese today know only dialect tokens (Kokuritsu Kokugo Kenkyūjo, 2013), and young and middle-aged speakers embed these tokens into a standard language matrix to stylise their talk (Inoue, 2000: 188-201). Nobody doubts their proficiency in standard language when doing so. This implies that young and middle-aged speakers are liberated from the stigma that was once attached to local dialects. Furthermore, stylising one's utterances with dialect tokens is imperative in colloquial speech, because the language of Tōkyō - that is, 'standard language' in the popular mind - is perceived as 'boring' (tsumaranai), 'cold, distant' (tsumetai) and 'not cute' (kawaikunai) (Tanaka, 2011: 28).

Other than token knowledge, stereotypes about local speakers are essential to stylise utterances by drawing on dialect tokens. Consider a few stereotypes that Tōkyō university students held about local dialect speakers (Table 14.1). The survey was conducted in 2007 and included 265 students. Dialects are again listed from northeastern to southwestern Japan. The number of students mentioning a particular stereotype is given in brackets.

In Table 14.1, we find popular and clear-cut stereotypical images of local inhabitants that are indexed by language. Put most simply, local dialects in the northeast but also in Ibaraki (central east) index their speakers as 'simple-minded', 'unstylish' and 'not cute'. Tōkyō dialect stands for little; it has lost any particular indexical function. It is 'boring' (= not interesting), 'cold', 'distant' (not intimate, warm) and 'not cute'. It stands for nothing. It embodies the negation of any emotional quality. It is therefore of little use for verbal stylisation, and it is for this reason that it lacks popularity (see Figure 14.1). By contrast, Western dialects stand for specific characteristics, Ōsaka dialect points at 'funny', 'frightening' and 'cool' speakers. The dialect is widely used in comedy programmes on 
Table 14.1 Linguistic stereotypes among Tōkyō university students

\begin{tabular}{ll} 
Local dialect & Stereotype \\
\hline Northeast & \\
\hline Hokkaidō & simple-minded (19), warm (17), gentle (14) \\
\hline Aomori & simple-minded (35), funny (21), unstylish (20), warm (18), not cute (17) \\
\hline Central East & \\
\hline Ibaraki & simple-minded (15), not cute (14) \\
\hline Tōkyō & boring (98), cold, distant (79), refined (54), not cute (21), cool (17) \\
\hline Central West & funny (123), frightening (85), cool (54), manly (34), cold (26), cute (22) \\
\hline Ōsaka & feminine (160), cute (98), refined (78), gentle (52), cool (18), warm (15) \\
\hline Kyōto & \\
\hline Southwest & manly (31) \\
\hline Fukuoka & manly (15) \\
\hline Kumamoto & warm (56), gentle (53), funny (48), cute (21), simple-minded (20) \\
\hline Okinawa &
\end{tabular}

Source: Adapted from Tanaka (2011: 28)

TV and in Yakuza (organised crime) films. The latter is due to the fact that the largest and most powerful Yakuza gangs are based in and around Ōsaka. Kyōto, the ancient capital, is on the other hand associated with 'feminine', 'cute', 'refined' and 'gentle' speakers. Women's language has been derived from and developed on the basis of the Kyōto dialect spoken at the Imperial court. 'Cuteness' is the central aesthetic feature of contemporary girl culture in Japan, and it is ubiquitous in popular culture and media. The southwest, finally, is associated with extreme 'masculine' behaviour, a perception that is reinforced by the great number of samurai films set in the southwestern island of Kyūshū, from which the samurailed Meiji Restoration started in the mid-19th century. The Meiji Restoration is a frequent topic of popular TV dramas. Okinawa, finally, is a popular sub-tropical tourist destination in Japan, and the tourist industry has been responsible for portraying Okinawans as laid-back, relaxed and gentle, and we find reflections of this invented image in the linguistic stereotypes assigned to Okinawan varieties.

What Tanaka (2011) calls 'dialect cosplay' (hōgen kosupre) is the use of dialect tokens to index specific traits of character or to simply evoke associations to the specific regions. Using dialect tokens can thus be employed to (a) index one's own regional background even if one no longer speaks this dialect (proficiently or habitually), (b) to index a regional background that is not one's own in a kind of 'regional role-play', e.g. pretending to be a northeastern person or (c) to evoke a specific stereotype, e.g. 'marked masculinity' by using, for example, southwestern dialect elements. 
Three things are important with such kinds of dialect-token language use for our discussion at hand.

- Firstly, 'dialect' can be put on or off. Hence, it is a feature of 'style' and not a new linguistic 'system' (see above). Even though most young and middle-aged Japanese speak only standard language, the meaning of an utterance stylised by dialect cosplay changes already according to the local origins of speakers and addressees. Somebody from Kumamoto using Kumamoto tokens can indicate their local background, whereas others can only use it to index 'local solidarity' with an addressee from Kumamoto, or to evoke the particular stereotype attached to it, in this case 'masculinity'.

- Secondly, as a result of using dialects as a 'costume', the semiotics are no longer clear and straightforward, as they were before people were socialised in Standard Japanese and used dialects proficiently as unmarked language in informal, local settings. Without context, stylised utterances do not make much sense (see also Abe, this volume),

- Thirdly, there is no risk of stigmatisation or inappropriateness involved in dialect cosplay. It is of no significance that northeastern dialects have had an extremely negative image, that the image of Ōsaka and Kyōto had been (more or less) neutral, or that of Tōkyō and its adjacent regions had been positive (Inoue, 1977). What counts are simply the stylistic effects that can be achieved by using dialect elements, and it is in this regard that Tōkyō dialect is of little utility and effect. Hence its lack of popularity.

Enregisterment via dialect cosplay involves acts of transgression. It is a means to step beyond one's 'bare self' (su no jibun) by using stylised expressions that index notions of regional background or stereotypical images of imagined speakers in a post-standard society (Tanaka, 2011: 16). The easiest and most popular way to engage in dialect cosplay is to use modal particles from local dialect when speaking or texting. Such particles are known 'character particles' (kyara gobi) in Japanese sociolinguistics (Table 14.2). These particles are generally known as interactional particles, and they express epistemic modality (Pizziconi \& Kizu, 2009). Different particles are used across Japan, and they are also used differently between social groups, e.g. between generations.

Table 14.2 illustrates in a simplified manner how local stereotypes and token knowledge of dialects can be applied to stylise utterances. Any given utterance can evoke the figure of someone who is 'simple-minded', 'funny', 'frightening', extremely 'manly', etc. simply by adding the respective kyara gobi at the end of a phrase. Kansai is the most frequently mimicked dialect in dialect cosplay. It is ubiquitous in contemporary language life, be that in mails, chats, jests, pop culture or the media.

The play with language for aesthetic or discursive effects does not only involve dialect, but at times employs notions of invented characters 
Table 14.2 Character particles and associated stereotypes

\begin{tabular}{lllll}
$\begin{array}{l}\text { Stereotype } \\
\text { Region }\end{array}$ & $\begin{array}{l}\text { simple-minded } \\
\text { (suboku) }\end{array}$ & $\begin{array}{l}\text { funny } \\
\text { (omoshiroi) }\end{array}$ & $\begin{array}{l}\text { frightening } \\
\text { (kowai) }\end{array}$ & $\begin{array}{l}\text { manly } \\
\text { (otokorashii) }\end{array}$ \\
\hline $\begin{array}{l}\text { Northeast Japan } \\
\text { (Tōhoku) }\end{array}$ & $\begin{array}{l}\text {-dabe, -dabesa, } \\
\text {-ppeka, -ndadomo }\end{array}$ & & \\
\hline $\begin{array}{l}\text { Central West } \\
\text { (Kansai) }\end{array}$ & $\begin{array}{l}\text {-yan, -yaro, -ya, } \\
\text {-nandeyanen }\end{array}$ & \\
\hline $\begin{array}{l}\text { Southwest Japan } \\
\text { (Chūgoku) }\end{array}$ & & $\begin{array}{l}\text {-yake, -kee, } \\
\text {-jaken }\end{array}$ & \\
\hline $\begin{array}{l}\text { Southern Japan } \\
\text { (Kyūshū) }\end{array}$ & & & -ken, -tai, -desutai, \\
\hline
\end{tabular}

Source: Compiled and adapted from Tanaka $(2011: 17-18,28)$

or roles. Role language (yakuwarigo) is another popular way of language stylisation in Japan (Kinsui, 2003). It basically functions like dialect cosplay. The main difference is that it 'plays' with something other than regional stereotypes. There exists a set inventory of linguistic elements that evoke specific figures when these are used in combination. This is again a case of enregisterment. Fixed figures, or 'roles' in Kinsui's terminology, include, for example, 'old man' (rōjin) or 'scientist' (hakase). In order to conjure these figures, one uses, for example, the first personal pronoun washi and the sentence final particle $-j a$. Such kind of language use is totally invented. It is not the case that real Japanese 'old men' or 'scientists' have ever spoken in this way. Rather, one encounters such use of language in manga and anime, and it is from there that it enters colloquial communication. Other roles such as 'cute girl', '(Western) foreigner', 'Chinese' or 'Korean' also exist, and there are set linguistic expressions available for enregistration. Assuming these figures in a speech act can be done for the sake of fun, but it can also be discriminatory or racist (for a detailed discussion, see Yamashita, 2019).

\section{Outlook and Conclusions}

Dialect cosplay employs linguistic elements that were once subject to correction and that stigmatised its speakers who therefore shifted to standard language. As most young and middle-aged Japanese speak today predominantly and often only the standard variety, the stigma of dialect has gone, and dialect tokens are utilised for stylistic effects in colloquial speech. This new form of colloquial speech is replacing Standard Japanese across Japan. Tōkyō colloquial speech plays a central role thereby, as most of Japan's popular culture and media are based in Tōkyō. Gone is the urge to 'pass' as a standard speaker and to use language 'appropriately' and 'correctly'. Passing is no longer a problem, and it is also no longer an objective for most. In informal settings that also include texting and 
communication via social media, we find a new purpose that speakers pursue: how illustrative, vivid, innovative and cool can you and your utterance be? Such use of language cannot be grasped as a 'system', and it cannot be studied out of context. It needs to be studied within the framework of third-wave sociolinguistics (Eckert, 2018). According to thirdwave sociolinguistic perspectives (Eckert, 2012: 88), speakers exploit 'linguistic variability in a systematic way to add a layer of social meaning to the denotational meaning that is the primary focus of most linguists'. Dialect cosplay and role language are linguistic behaviours that aim at adding a new layer of social meaning.

The sociolinguistics of distribution, i.e. mapping language on territory or on a specific social stratum, to specific age cohorts or milieus no longer works to study such post-standardisation language behaviour. The sociolinguistic situation is ambiguous, ambivalent and contingent. In other words, modernity is over. We not only have to study language in its present-day social settings but also our research design and methodology must do justice to the contemporary situation (see Zhao, this volume). In such contexts, new types of speakers and learners, various degrees of language ownership, poly- and translanguaging and linguistic transgressions can be widely observed.

The study of 'standard language' and 'dialects' was not so long ago a 'bread-and-butter' topic of any linguist. Linguistics had developed methods to describe the two, relate them to one another and to predict their uses. The case of Japan shows us that the sociolinguistic situation on which our understanding of standard language and dialect are based has only been temporary. Once standardisation is completed, changes in attitudes and uses come to the fore that do not allow us to apply the modernist methods developed in the 20th-century to 21st-century late-modern societies. Dialects no longer give their speakers away, and standard language loses many of its social indexical functions. Consequently, we have to shift focus from 'language varieties' to 'language repertoires', from (national and local) 'speech communities' to 'individual speakers', and from 'domain' to 'context'. We can witness the first steps of such changes in contemporary Japanese sociolinguistics in the work I have discussed here, and given the prominence and the impact of new, post-standard and late-modern language uses we can find there today, we can expect many more new insights and methods to emerge from the case of Japan.

This chapter has, admittedly, only scratched the surface of dialect cosplay in Japan. It nevertheless points at the necessity to flesh out the sociocultural particularities of language de-standardisation of which dialect cosplay and role language are part. Such a sociocultural history of language and communication would need to lay bare the mechanisms by which individual speech acts became socially replicable. How did individual speech acts come to enregister their speakers as figures with set (stereotypical) sociocultural values? How did these processes and 
behaviours shape the linguistic habitus of large parts of Japan's young and middle generation? These are questions that await a systematic study in Japan. The role of mediatised language use will have to play a prominent role in such an endeavour.

\section{Notes}

(1) I would like to thank the editors for inviting me to contribute to this volume. I am also grateful for the insightful comments and suggestions by two anonymous reviewers which helped me to add precision to my arguments. Remaining errors and shortcomings are mine.

(2) 'Passing' is very much the contrary to 'transgressing', i.e. a conscious effort to be recognised as a member of a community (social class, ethnicity, gender, sexual orientation, linguistic, etc.) that is different from one's own.

(3) Due to limits of space, this chapter does not provide for discussion of language and media. Interested reader may confer to Matsushita (2012); Tsukahara and Heinrich (2013); Zawiszová (2018) or Yamashita (2019).

\section{References}

Agha, A. (2003) The social life of cultural value. Language \& Communication 23, 231-273.

Agha, A. (2007) Language and Social Relations. Cambridge: Cambridge University Press.

Aizawa，M. (2012) 方言意識の今をとらえる・「2010年全国方言意識調查」と統計分析 [Research on present-day dialect consciousness. Nationwide survey in 2010 and its statistical analyses]. 国語研プロジェクトレビュー [Review of National Language Institute Projects] 3 (1), 26-37.

Bauman, Z. (1992) Intimations of Postmodernity. London: Routledge.

Cornips, L. (2012) 'Straattaal' is (g)een andere taal [Street language is (not) another language]. In L. Cornips (ed.) Eigen und Vreemd [Known and Unknown] (pp. 75-82). Amsterdam: Amsterdam University Press.

Coulmas, F. (1985) Sprache und Staat [Language and the State]. Berlin: de Gruyter.

Coulmas, F. (2016) Guardians of Language. Oxford: Oxford University Press.

Eckert, P. (2008) Where do ethnolects stop? International Journal of Bilingualism $12(1 / 2), 25-42$.

Eckert, P. (2012) Three waves of variation study. The emergence of meaning in the study of sociolinguistic variation. Annual Review of Anthropology 41, 87-100.

Eckert, P. (2018) Meaning and Linguistic Variation: The Third Wave in Sociolinguistics. Cambridge: Cambridge University Press.

Garvin, P.L. (1993) A conceptual framework for the study of language standardization. International Journal of the Sociology of Language 100/101,37-54.

Goffman, E. (1979) Footing. Semiotica 25, 1-29.

Heinrich, P. (2005) Things you have to leave behind: The demise of 'elegant writing' and the rise of genbun itchi style in Meiji-period Japan. Journal of Historical Pragmatics $6,113-132$.

Heinrich, P. (2012) The Making of Monolingual Japan: Language Ideology and Japanese Modernity. Bristol: Multilingual Matters.

Heinrich, P. (2013) Hōgen ronsō: The great Ryukyuan languages debate of 1940. Contemporary Japan 25 (2), 167-187.

Heinrich, P. (2018a) New presentations of self in everyday life: Linguistic transgressions in England, Germany and Japan. In R. Bassiouney (ed.) Identity and Dialect Performance (pp. 281-407). London: Routledge. 
Heinrich, P. (2018b) Dialect cosplay. Language use by the young generation. In P. Heinrich and G. Galan (eds) Being Young in Super-Aging Japan (pp. 166-182). London: Routledge.

Heinrich, P. and Galan, C. (eds) (2018) Being Young in Super-Aging Japan. London: Routledge.

Heinrich, P., Miyara, S. and Shimoji, M. (eds) (2015) Handbook of the Ryukyuan Languages. Boston: de Gruyter Mouton.

Heinrich, P. and Yamashita, R. (2018) Tokyo. Standardization, ludic language use and nascent superdiversity. In D. Smakman and P. Heinrich (eds) Urban Sociolinguistics. The City as a Process and Experience (pp. 130-147). London: Routledge.

Inoue, F. (1977) 方言イメージの多变量解析 [Multivariate analysis of dialect image]. 言語 生活 [Language Life] 311, 82-91.

Inoue, F. (2000) 日本語の值段 [The Price of Japanese]. Tōkyō: Taishūkan.

Inoue, F. (2011) Standardization and de-standardization processes in spoken Japanese. In P. Heinrich and C. Galan (eds) Language Life in Japan: Transformations and Prospects (pp. 109-123). London: Routledge.

Inoue, F. and Yarimizu, K. (2002) 辞典・新しい日本語 [Dictionary of New Japanese]. Tōkyō: Tōyō Shorin.

Inoue, M. (2006) Vicarious Language: Gender and Linguistic Modernity. Berkeley: University of California Press.

Jugaku, A. (1978) 標準語の問題 [Standard language problem]. In E. Chino (ed.) 岩波講 座日本語 [Iwanami's Course on Japanese] (Volume 3, pp. 52-55). Tōkyō: Iwanami.

Katō, H. (1880) 議案 [Proposal]. 東京学士会員雑誌 [Journal of the Academic Society Tokyo] 2 (1), 189-194.

Kinsui, S. (2003) ヴァチャル日本語・役割後の謎 [Virtual Japanese: The Mystery of Role Language]. Tōkyō: Iwanami.

Kobayashi, T. (ed.) (2018) コミュニケーションの方言学 [The Dialectology of Communication]. Tōkyō: Hitsuji Shuppan.

Kokugo Chōsa I'inkai (2000 [1916-1917]) 口語法 [A Grammar of Spoken Language] (reprint). Tōkyō: Bensei Shuppan.

Kokuritsu Kokugo Kenkyūjo (2013) 第四回鶴岡市における言語調査結果の概要 [Results and Overviews of the 4th Language Survey in Tsuruoka City]. Tōkyō: Kokuritsu Kokugo Kenkyūjo.

Labov, W. (1972) Some principles of methodology. Language and Society 1 (1), 97-120.

Lee, Y. (2010) The Ideology of Kokugo: Nationalizing Language in Modern Japan. Honolulu: University of Hawai'i Press.

Machida, K. (2009) 変わる日本語 [Japanese that Is Changing]. Tōkyō: Seitōsha.

Maher, J.C. (2005) Metroethnicty, language and the principle of cool. International Journal of the Sociology of Language 175/176, 83-102.

Masiko, H. (1997) イデオロギーとしての「日本」 ['Japan' as an Ideology]. Tōkyō: Sangensha.

Matsushita, K. (2012) デイジタルネイテイブとソーシャルメディア・若者が生み出す新たなコミ ュニケーション [Digital Natives and Social Media. New Communication Produced by the Young Generation]. Tōkyō: Kyōiku Hyōronsha.

Mizuhara, A. (1994) 江戸語、東京語、標準語 [Edo Language, Tokyo Language, Standard Language]. Tōkyō: Kōdansha.

Murata, K. (ed.) (2015) 共生の言語学・持続可能な社会を目指して [Welfare Linguistics. Toward a Sustainable Society]. Tōkyō: Hitsuji Shuppan.

NHK (1979) 日本人の県民性 [Prefectural Characteristics of Japanese People]. Tōkyō: NHK.

Nieser, M. (2007) Le Verlan: Règles et Usages. München: GRIN.

Nomura, T. (2011) 話し言葉の日本史 [Japanese History of Spoken Language]. Tōkyō: Yoshikawa Kōbunkan. 
Nomura, T. (2013) 日本語スタンダードの歴史 [History of the Japanese Standard]. Tōkyō: Iwanami.

Okamoto, S. and Shibamoto-Smith, J.S. (2016) The Social Life of the Japanese Language. Cambridge: Cambridge University Press.

Osa, S. (1998) 近代日本と国語ナショナリズム [Modern Japan and Language Nationalism]. Tōkyō: Kikawakō Bunkan.

Pizziconi, B. and Kizu, M. (eds) (2009) Japanese Modality: Its Scope and Interpretation. London: Palgrave Macmillan.

Pountain, D. and Robins, D. (2000) Cool Rules: Anatomy of an Attitude. London: Reaktion Books.

Rampton, B. (2005) Crossing: Language and Ethnicity among Adolescents. Manchester: St. Jerome Publishing.

Renfrow, D.G. (2004) A cartography of passing in everyday life. Symbolic Interaction 27 (4), 485-506.

Sanada, S. (1996a) 滋賀県今頭町、福井県上中町言語調査報告 [Shiga Prefecture, ImazuTown and Fukui Prefecture, Kamakura-City language survey report]. 大阪大学文学 部紀要 [Bulletin of the Faculty of Letters of Osaka University] 36, 31-64.

Sanada, S. (1996b) 地域語のダイナミズム [Dynamism in Dialects]. Tōkyō: Ōfū.

Sanada, S. (2000) 脱・標準語の時代 [The Age of De-Standardization]. Tōkyō: Shōgakukan Bunko.

Satō, K. and Yoneda, M. (eds) (1999) どうなる日本のことば・方言と共通語の行方 [What Will Happen to Language in Japan? The Future of Dialects and Standard Language]. Tōkyō: Taishūkan.

Shimizu, Y. (1990) 近代国語史研究の視点 [The perspective of modern national language studies]. 国文学・解釈と鑑賞 [Interpretation and Appreciation of National Literature] 55, 121-126.

Shioda, T. (2011) Constraints on language use in public broadcasting. In P. Heinrich and C. Galan (eds) Language Life in Japan (pp. 124-139). London: Routledge.

Sibata, T. (1958) 日本の方言 [Japan’s Dialects]. Tōkyō: Iwanami.

Sibata, T. (1977) 標準語、共通語、方言 [Standard language, common language, dialect]. In Bunkachō (ed.) 標準語と方言 [Standard Language and Dialect] (pp. 22-32). Tōkyō: Bunkachō.

Silverstein, M. (2003) Indexical order and the dialectics of sociolinguistic life. Language \& Communication 23 (3/4), 193-229.

Sugimoto, T. (2014) 東京語の歴史 [History of Tokyo Language]. Tōkyō: Iwanami.

Tanaka, A. (1999) 日本語の位相と位相差 [Japanese Registers and Register Variation]. Tōkyō: Meiji Shoin.

Tanaka, Y. (2007) 着脱される「属性」・方言「おもちゃ化」現象 [Distinctive features put on and off. The dialect as a toy phenomenon]. See http://skinsui.cocolog-nifty.com/ sklab/files/JASS19tanaka.pdf (accessed 16 November 2018).

Tanaka, Y. (2011) 方言コスプレの時代 [The Age of Dialect Cosplay]. Tōkyō: Iwanami Shoten.

Tanaka, Y, Hayashi, N., Maeda, T., et al. (2016) 一万人加見たから最初の方言、共通語 意識 [Latest Trends in Nationwide Language Consciousness and Standard Language of 10,000 People]. Tōkyō: NINJAL.

Tsukahara, N. and Heinrich, P. (eds) (2013) ネット時代のことばと社会 [Language and Society in the Internet Age]. Tōkyō: Sangensha.

Wiese, H. (2012) Kiezdeutsch: Ein neuer Dialekt entsteht [Kiezdeutsch: A New Dialect Emerges]. München: Beck.

Yamashita, H. and Noro, K. (eds) (2001) 「正しさ」への問い・批判社会言語学の試み [Questioning Correctness. An Attempt in Critical Sociolinguistics]. Tōkyō: Sangensha. 
Yamashita, H., Watanabe, M. and Takada,H. (eds) (2011) 言語意識と社会・ドイツの視点、 日本の視点 [Language Awareness and Society. German and Japanese Perspectives]. Tōkyō: Sangensha.

Yamashita, R. (2019) Codeswitching, language crossing and mediatized translinguistic practices. In P. Heinrich and Y. Ohara (eds) The Routledge Handbook of Japanese (pp. 218-234). London: Routledge.

Zawiszová, H. (2018) On 'Doing Friendship' in and through Talk. Exploring Conversational Interactions of Japanese Young People. Olomouc: Palacký University Press. 